\title{
GENDERED NARRATIVES OF RURAL SOCIAL ENTERPRISES IN FASHION: CONSTRUCTING NEW SOCIOLOGICAL IMAGINATIONS IN INDIA
}

\author{
Shaira Vohra \\ Burlingame High School \\ DOI: 10.46609/IJSSER.2020.v05i02.012 URL: https://doi.org/10.46609/IJSSER.2020.v05i02.012
}

\begin{abstract}
A primary mode of both rural and gender empowerment in the Indian context, cognizant of trends in indigenous production of capital and products in present economic conditions, is social innovation and entrepreneurship -- through targeted incentivization of women's participation in the labor force and consistent encouragement of wage equality. This paper examines gendered narratives of rural social enterprise functioning and development, focusing on the fashion and accessory industry. Through a combination of ethnographic and sociological perspectives, the study looks at Indian case studies of rural enterprises and their efforts to foster gender empowerment through financial, sociopolitical, and economic forms. This will be considered through the following factors:- i) employment of women labourers; ii) female leadership and membership in higher organizational hierarchy; iii) improving access for women through demasculinized hiring practices; iv) reducing the wage gap; v) undoing regressive social moralities regarding working women. Thus, the paper is a study in social enterprise development to provide a map to future entrepreneurs and policy makers for more inclusive solutions to rural issues and provide a fresh sociological imagination cognizant of ground-level cultural realities in the subcontinent.
\end{abstract}

Keywords: Gendered, Rural, Social, Sociopolitical, Financial

\section{INTRODUCTION}

Gender Inequality is a reality faced by women in communities across India- especially those who reside in the rural parts of the country. Inequalities trace their origin to patriarchal social norms manifest in the form of unequal access to healthcare, education, economic opportunities and political power. Since Indian Independence, central policymakers have taken cognizance of 


\section{International Journal of Social Science and Economic Research}

ISSN: $2455-8834$

Volume: 05, Issue: 02 "February 2020"

gender inequalities in India which disadvantages women in their attempt to achieve self actualization (Hanmer, 2000). The Constitution of India not only guarantees women equal social, economic and political rights but also provides for affirmative action for women through reservations and other instruments of public policy. Campaigns aiming to achieve equality in India for women have been numerous and unsuccessful, and different political parties have sought to introduce programs that succeed in changing the 'unequal playing field' that impacts women unfairly. Markers of development such as the literacy rate reflect the exclusion of women from narratives of development. The literacy rate for men is $75.7 \%$ and for women is $62 \%$ in India, implying that men are more likely to avail quality employment, achieve social mobility, and participate in the process of development (NSS, 2014). The failure of these campaigns and programs occurs because of their inability to tackle the complex and contextual sociology behind the oppression of women in different parts of India.

Gender Inequality manifests in complex ways and impacts women differently based on their socio-economic background and the identities they ascribe to. Private investment, public policy and the influence of western liberal ideas have led to the relative improvement of the unequal playing field in Urban India (Ghose, 2001). However, rural India- where the majority of the population resides has been excluded from the socio-economic development that India has experienced since the introduction of globalization-friendly policies in 1991. Distant from western education, progressive discourse and elements of popular culture that emphasizes on gender equality and women's empowerment; communities in most parts of rural India continue to adhere to stringent patriarchal norms that derive their legitimacy from the oppression of women. The literacy rate for women in rural India ( 56.8\%) is much worse than both- the literacy rate for women in urban areas (74,3\%) and the literacy rate of men in rural areas $(72.3 \%)$ which goes on to show how rural women are amongst the most oppressed communities in India (NSS, 2014)). The growth of Private industry in India has been responsible for the development of multiple sectors and geographical regions (Pande, 2007). However, rural women continue to face oppression within multinational companies and centrally owned private businesses. The absence of labor laws in the unregulated economy of India has allowed businesses to set up sweatshops that force women and children to work under inhumane conditions for very low wages (Kundu, 2003). Moreover, the presence of social bias against women and the mysogynstic mindsets of 'managers' at the rural level has led to physical and sexual abuse of women in private factories owned and controlled by men. In a space where both private and public investment have not only failed to empower women but have further contributed to the oppression of women by subjecting them to operate in the capitalist patriarchal structure, there is a need for communities in rural India and the government to explore an empower non-conventional of forms of industry in rural India. 


\section{International Journal of Social Science and Economic Research}

ISSN: $2455-8834$

Volume: 05, Issue: 02 "February 2020"

Rural Industries in India have historically been operated by joint families- a system in which members of an extended family (usually from the same caste and sub-caste) pool their economic resources and engage in business activities that work in the agricultural, forest or handloom sector. However, there has been a recent growth in rural self help groups and cooperativesorganizations consisting of individuals who are engaged in a particular trade or of individuals who ascribe to a particular identity. Self Help Groups help approximately 33 million of Indian women to obtain financial services and other activities with lower prices and have pioneered the fight for women's empowerment in rural India (Sankaran, 2018). By encouraging women to start businesses that they have expertise in- such as the handloom industry, they make economic opportunities more accessible to them. Moreover, the development of self help groups and other female led industries in rural areas have not only contributed to regional economic development but have also been associated with the eliminating gender inequality (Lombe et. al., 2012).

\section{BACKGROUND}

In rural India, businesses primarily operate in three distinct industries- agriculture, forest, and handloom industries. Skills that give every rural industry a distinct identity and are passed on from generation to generation, are homogeneous within a particular region but vary significantly between different parts of India. For example- the rural populace of Kashmir is considered to be proficient in carpet weaving- which is a reflection of not only the climatic conditions and natural resources of Kashmir but also provides an insight into the social traditions of the valley (Anandram \& Mehda, 2009). Agriculture and associated industries have historically been considered vital for the economy of rural India because they employed the majority of the rural population. However, technological advancements and urbanization have contributed to the sinking of the agriculture sector from $68 \%$ to $16.1 \%$ of the Gross Domestic Product between 1970 and 2009 (Sandhu, et. al., 2012). On the other hand, non-agricultural industries have grown progressively at a significant rate and now account for $86 \%$ of the rural economy (Tiwari, 2015).

Cooperatives initially originated in rural India in the twentieth century to carter to the financial needs of farmers. Cooperatives are responsible for $65 \%$ of the rural credit available to all rural industries. Unlike centralized banks and financial organizations, these cooperatives better handle the contextualized problems of female entrepreneurs in different parts of the country. Moreover, them being devoid of a profit motive increases the propensity of them acting in 'good-faith' and not using predatory lending practices (Anandram \& Mehda, 2009). On the other hand, Self-Help Groups commonly comprises 10 to 20 members who mutually fund money for setting up enterprises that operate in a similar market and produce similar commodities. Self Help Groups have pioneered microcredit in India- a system through which individuals from economically weaker backgrounds are given loans of a small amount at a very low-interest rate that enables 


\section{International Journal of Social Science and Economic Research}

ISSN: $2455-8834$

Volume: 05, Issue: 02 "February 2020"

them to set up their business enterprises and facilitates entrepreneurship. Research has determined that there is an improvement in the aspects of psychological and economic conditions of rural women after accessing such microfinance (Lombe, et. al., 2012). The handloom industry has specifically had a tradition of unique craftsmanship that is representative of the cultural identity of the people and has gained international repute for expertise in hand spinning, weaving, and printing. Globalization has led to a sharp increase in demand for organically and authentically produced clothes and accessories. This authenticity requires the usage of traditional procedures and skills that have been passed generationally amongst rural women (FICCI, 2019). The higher purchasing power of western consumers has been a definitive driver for enterprises operating in the 'fashion' sector in rural India.

Even though women have been kept outside the fold of the formal economy, they form a bulk of the agricultural workforce. With the mechanization of agricultural practices, many women, especially those from backward castes have lost their means of employment and sustenance. The decrease in the employment of women in the agricultural sector is reflected in the national decrease in the participation of women in the workforce. The participation of women in the workforce has decreased from $36.9 \%$ to $22.5 \%$ between 2004 and 2018 which shows the reduction in economic opportunities available to the most oppressed women of India. This decrease is caused mostly by the reduction of women in the rural workforce which has fallen from $49.4 \%$ to $24.6 \%$ over the past 15 years (Rukmini, 2019) The development of rural industries in sectors that women tend to have an expertise in is imperative to increase the participation of women in the Indian economy and workforce.

\section{DISCUSSION}

Rural organizations that work for the empowerment of women may operate in the form of a selfhelp group, a registered NGO, a rural cooperative or a combination of some or all of these. They seek to work with women, especially those belonging to 'backward' castes to fill gaps created by the lack of access to formal education and public healthcare and increase their integration with the formal economy and public welfare programs. Moreover, given that rural areas usually face the worst impacts of environmental pollution and these fashion enterprises tend to be more sustainable than international brands.

Anchal is a social enterprise in rural India that works to uplift women who have been victims of domestic violence by training them in design and by employing them in the textile industry. Anchal has worked with over 150 women and has trained 77 artisans as of 2017.'Okhai' is an enterprise launched by the 'Tata Chemicals Society for Rural Development (TCSRD) as Corporate Social Responsibility (CSR) initiative that operates in the drought-prone Okhamandal 


\section{International Journal of Social Science and Economic Research}

ISSN: $2455-8834$

Volume: 05, Issue: 02 "February 2020"

region of Gujarat that operates on the principle of 'Working Women for Working Women' (Raj, 2017). It has led to a resurgence in the handloom industry by working with local entrepreneurs who specialize in the production of the 'Okhamandal style' of mirror work, patchwork, and embroidery (Sathyendran, 2014). 'Mother Earth' works with Self Help Groups (SHGs) or independent local rural entrepreneurs by guiding them towards innovative designs and provides the necessary support in the process of marketing these commodities in the national and international market. The process of connecting rural producers with the international market has been a key driver of the rural fashion industry because of the demand for organically produced commodities combined with the premium cultural value of indigenous industries. Similarly, Pashm seeks to connect international level designs with rural artisans. The designs for accessories are made in Amsterdam, Netherlands but the production and weaving are primarily done by the rural Indian artisans. The usage of natural products including Himalayan forest silk, nettle and wool commands high value in the eyes of European and American customers and has contributed to the growth in economic opportunities available to the rural artisans. The not for profit sector is also characterized by cooperation between organizations which differentiates it from the mainstream profit-driven market. Mandala Apparels, a company with a majority female workforce that produces organically apparel and aims to inclusive clothing sends its waste to Goonj, an urban NGO where old clothes are used to manufacture sanitary napkins for underprivileged women (Raj, 2017).

Rural Enterprises working in the fashion sector contribute to the participation of women in the workforce. This is because the skills required in producing commodities marketed by these organizations have been passed on from generation to generation of rural women as a symbol of cultural identity. The lack of access to formal education reduces the propensity of rural women developing skills necessary to work in the formal economy. However, rural enterprises fill this gap by centering economic activity around the skills acquired by these women throughout their lives. This has also reduced the economic burden of unemployment caused by the mechanization of agriculture by increasing the ability of women to participate in the workforce and contribute to economic activity. The remuneration and profits generated by female workers and entrepreneurs are key in reducing the waste gender pay gap that exists in India, primarily due to the fact that women perform most unpaid labor in the country (Catalyst, 2019). The employment of women also leads to the creation of more accessible and equitable workspaces that are starkly different from the conventional hypermasculine factories in India- which are rarely conducive and sensitive to the needs of women. The development of 'All-Female' enterprises has also created a safe space for those women who have been victims of gendered violence- a social evil that India continues to struggle with (Catalyst, 2019). Most of these enterprises, including Pashm, are characterized by the presence of strong female leadership. Not only does this prevent predatory practices common in all structures where men hold positions of power (universities, media 


\section{International Journal of Social Science and Economic Research}

ISSN: $2455-8834$

Volume: 05, Issue: 02 "February 2020"

houses, etc.), female leaders in the rural setting act as role models to young women and help in dispelling conservative narratives that restrict women to the role of a homemaker and paint them as incapable leaders and entrepreneurs. Perhaps the most beneficial long term impact of the growth of female-led rural enterprises is the generation of discourse that is inherently feminist and repels regressive social moralities surrounding women and the labor performed by them in India.

Despite their rural fashion enterprises continue to face certain systemic and structural challenges in rural India. These include limited capital, an unsteady communication system, and the absence of strong transport infrastructure. These obstacles are a result of the failure of state governments to make the business environment conducive to the needs of female-led enterprises in rural India. The deficit of knowledge in marketing and finance increases the propensity of improper managerial decisions. However, the largest obstacle continues to be the social opposition to the employment of women which can lead to domestic abuse and often forces women to make difficult trade-offs between their family and work (Kar, 2012). The removal of these obstacles for enterprises in rural areas is associated with the creation of a higher-value market that operates at the international level (Misra, 2008).

\section{CONCLUSION}

Rural enterprises that produce clothes and accessories have been responsible for the empowerment of women belonging to the most oppressed communities by providing them the means to achieve socio-economic mobility. However, their growth in India has been restricted because of two primary reasons- the lack of public support and the exclusive reliance on traditional experiences and knowledge which is often incompatible with the modern globalized market that they operate in and seek to carter (Anandram \& Mehda, 2009). The solution to this problem lies in the form of increased support to rural enterprises by the local and state governments in the form of infrastructural development and assistance in integration with the formal economy and market. Secondly, there is a need for such enterprises to evolve with the changing marketing environment and adopt modern techniques of marketing and management to remove inefficiencies in operations. The emergence of e-commerce has been instrumental in the development of small scale businesses in urban regions (NewsLocal, 2017). Increased internet penetration has opened up the online marketplace to rural retailers (Mathur, 2019). Accessing ecommerce can solve multiple problems that rural enterprises face in accessing global markets. The development of rural fashion enterprises promises to improve the wage gap by increasing the economic productivity of female laborers; tackling regressive narratives surrounding women in positions of power by promoting female leadership and membership at higher levels in the 
International Journal of Social Science and Economic Research

ISSN: $2455-8834$

Volume: 05, Issue: 02 "February 2020"

organizational hierarchy, and developing safe spaces for women, not just limited tom but beyond the workplace. 


\section{International Journal of Social Science and Economic Research}

ISSN: $2455-8834$

Volume: 05, Issue: 02 "February 2020"

\section{BIBLIOGRAPHY}

Anandaram, K, Medha, D. (1999). Role of cooperatives in social development. Indian Journal of Industrial Relations. Accessed on 28th January 2020

Catalyst (2019). Women in the Workforce - India: Quick Take. Accessed on 29th January 2020

Dijkstra, H. (2000). Measuring socio-economic gender inequality: Toward an alternative to the UNDP gender-related development index. Feminist Economics. Accessed on 25th January 2020

Federation of Indian Chambers of Commerce and Industry. (2019). Indian Handloom IndustryPosition Paper. Accessed on 28th January 2020

Ghose, T.R. (2001). A critical note on UNDP's gender inequality indices. Journal of Contemporary Asia. Accessed on 26th January 2020

Kar, S.K. (2012). Knowledge process of rural handloom community enterprise: A narrative study of Sambalpuri Bastralaya in India. Society and Business Review. Accessed on 28th January 2020

Kundu, S.C. (2003) Workforce diversity status: a study of employees' reaction. Industrial Management \& Data Systems, Accessed on 26th January 2020

Lombe, M., Newransky, C., Kayser, K., Raj, P. (2012). "Exploring Barriers to Inclusion of Widowed and Abandoned Women through Microcredit Self-Help Groups: The Case of Rural South India". Journal of Sociology and Social Welfare. Accessed on 27th January 2020

Mathur, N. India's internet base crosses 500 million mark, driven by Rural India. Livemint, 11th March 2019

Misra, H. (2008). Prospects and challenges in implementing e-business strategies for rural enterprises: A case of dairy cooperative in India. Accessed on 25th January 2020

National Sample Survey of India (2014). Literacy and Education. Ministry of Statistics and Programme Implementation, Accessed on 28th January 2020

Newslocal. The benefits of e-commerce for small business. The Daily Telegraph, 5th June 2017 
Pande, A. (2007). Explaining son preference in rural India: The independent role of structural versus individual factors. Population Research and Policy Review. Accessed on 25th January 2020

Raj, N. (2014). 10 Fashion Labels As Social Enterprise. Impactpreneurs. Accessed on 26th January 2020

Rukmini, S. India's workforce is masculinizing rapidly, Livemint, 10th June 2019

Sandhu, N. Hussain, J. Matlay, H. (2012). Barriers to finance experienced by female owner/managers of marginal farms in India". Journal of Small Business and Enterprise Development. Accessed on 28th January 2020

Sankaran, V (2018). "Entrepreneurship for Women Self Help Groups. Sumedha Journal of Management". Sumedha Journal of Management. Accessed on 27th January 2020

Sathyendra, N. All the way from Okhamandal. The Hindu, 10th July 2014

Tiwari, S. (2015). Managing Transformation of Rural India through Rural Non-Farm Economy. Journal of Rural and Industrial Development. Accessed on 28th January 2020 